\title{
Testosterone Level Finding
}

National Cancer Institute

\section{Source}

National Cancer Institute. Testosterone Level Finding. NCI Thesaurus. Code C157377.

A finding that indicates the amount of testosterone in a sample. 